\title{
Retrieving the hidden everyday spaces of infants'
}

lovise Holt²

Abstract: In this paper I explore the possibilities of investigating the everyday spaces of infants and young children. Overall infants and young children have been overlooked as research partners in critical geographies and social studies of childhood. The marginalisation of infants and young children as agents in research reflects earlier concerns about the neglect of children in sociology and human geography. Where infants have appeared in sociology or human geography, they have tended to be constructed as 'objects of care' (e.g. in feminist research) and/ or 'objects of analyses' (e.g. within population geography). In this paper I argue that exploring the social and spatial experience of infants critiques dominant assumptions about (children's) agency and can provide fruitful insights into processes of subjectification and the reproduction of embodied inequalities. I suggest three potential agendas for researching infants, in which I engage in a preliminary

1 Acknowledgements: Thanks go to the mothers and infants who participated in the research. Thanks also to Sophie Bowlby for insightful comments on an early draft of this paper, to Peter Kraftl for thought provoking comments on a presentation of this paper, and to Maria Prats, Mireia Baylina, Anna Ortiz and Maria Delores Garcia-Ramon for inviting me to present an early version of this paper at the Second International Conference of Geographies of Children, Youth and Families, Universitat Autònoma de Barcelona,Spain, 16-18 July 2009. Versions of this paper have been presented at the $4^{\text {th }}$ International Conference of Geographies of Children, Youth and Families in San Diego, 11-15 January 2015 and papers on a similar theme were presented at the Geographies of Young Children, Session co-organised with Stuart Aitken, at the RGS/IBG International Conference, London $3^{\text {rd }}$ September 2016 \& Geographies of Early Childhood, AAG San Francisco, 30 March $-4^{\text {th }}$ April, 2016, with Stuart Aitken. Thanks to Gabriela Tebet whose work on a similar theme I discovered at the $4^{\text {th }}$ International Conference on Geographies of Children, Youth and Families in San Diego, and with whom I have since collaborated, and to Anete Abramowicz for the invitation to submit this paper.

2 Geography and Environment - Loughborough University - Loughborough - UK - l.holt@lboro.ac.uk 
analysis, drawing upon ethnographic research in a children's centre - parent/carer infants and micro-mobilities; moral geographies of specific infant/parent/carer focused spaces; micro-infant geographies, infant agency/subjectivity and subjectification in specific spaces and times; broader socio-economic inequalities reproduced in infant subjectivities: habitus. The penultimate section discusses some of the methodological and ethical complexities of researching with infants, and questions how (and if) these can be overcome.

Key Words: Babies; early childhood; children's geographies; inter-embodiment; habitus.

\section{REAVENDO OS ESPAÇOS DIÁRIOS ESCONDIDOS DE BEBÊS}

Resumo: Neste artigo, exploro as possibilidades de investigar os espaços cotidianos de bebês e crianças pequenas. No geral, bebês e crianças pequenas foram negligenciados como parceiros de pesquisa em geografias críticas e estudos sociais da infância. A marginalização de bebês e crianças pequenas como agentes na pesquisa reflete preocupações anteriores sobre a negligência das crianças na sociologia e na geografia humana. Nos momentos em que os bebês apareceram na sociologia ou na geografia humana, eles tenderam a ser construídos como "objetos de cuidado" (por exemplo, na pesquisa feminista) e/ ou "objetos de análise" (por exemplo, na geografia populacional). Nesse artigo, argumento que explorar a experiência social e espacial dos bebês é uma crítica às suposições dominantes sobre a agência (infantil) e pode fornecer percepções proveitosas sobre os processos de subjetivação e reprodução das desigualdades corporificadas. Sugiro três agendas potenciais para a pesquisa com bebês, nas quais me envolvo em uma análise preliminar, com base em pesquisa etnográfica em um centro de crianças - pais/ cuidadores de bebês e micro-mobilidades; geografias morais de espaços específicos para bebês/ pais/ cuidadores; geografias micro-infantis, agência/ subjetividade infantil e subjetivação em espaços e tempos específicos; desigualdades socioeconômicas mais amplas reproduzidas nas subjetividades infantis: habitus. A penúltima seção discute algumas das complexidades metodológicas e éticas da pesquisa com bebês, e questiona como (e se) elas podem ser superadas.

Palavras-chaves: Bebês; Primeira Infância; Geografia da Infância; Inter-corporeidade. 


\section{Introduction}

The idea of exploring the socio-spaces of infants and young children emerged as when I was invited to deliver a lecture for which I wrote this paper, I had just finished my first maternity leave. I wondered what I could write about, given I had spent the best part of a year in a wonderful, often carefree, often fraught and emotional, overwhelming and all-consuming baby and mother space. And the answer was staring back at me from Rhea's ${ }^{3}$ quizzical expression.

Before I started my first maternity leave my husband and I jokingly labelled it my sabbatical. Although I realized that I would have plenty to do, in my naiveté I was also intending to catch up with all my reading. I had envisaged that in the early months, I would have lots of time as Rhea slept during the day - and when I wasn't catching up with my own sleep I would read articles and books both academic and instructions about how to be a parent. How Rhea wonderfully intruded her own self on my plans. How much agency that baby had to totally turn our lives upside down. Now, in light Rhea and her sister and brother, I continue to be intrigued by the way the individual personalities of the infants challenged all my expectations of parenting, and everything I thought I had learned along the journey - about sleeping, feeding, and teaching how to be in the world.

With Rhea mother and baby time was, overall, a relatively happy, fluffy bubble, but this was clearly influenced by my socio-spatial positioning; the broader political economy and my little family's relatively affluent position therein, and my social support networks (Katz, 2017). Our family's position of gentrifiers was also significant; living in an area characterized by disinvestment and a high level of socio-economic exclusion meant we had access to all the resources targeted at improving the opportunities for infants from socio-economically excluded backgrounds, along with all the other local middle-class families. Although faced with a different set of challenges in each subsequent maternity leave, including the emotional ups and downs brought on by hormones and lack of sleep, each time I realise I had a privileged position, with access to healthcare, advice and resources a plenty. I was able to take extended maternity leaves facilitated by both my relatively affluent position and UK legislation. Moving home and job shortly before the birth of my second child highlighted the importance of socio-spatial contexts to parenting young children, as the framework of support which I relied on shifted from the children's centres, which for the most part were being dismantled, to the health care sector and the voluntary sector. Our 
move coincided with increasingly Austerity in the UK when state resources were being increasingly drawn back and targeted on those with the greatest need.

During my first maternity leave, at the same time as I was so consumed by being a new mother, as a children's geographer, I became intrigued about why had I read so few geographical or social studies that really included infants as agents. These are some of the questions I want to begin to approach in this paper. Although primarily theoretical/conceptual in focus, the paper also occasionally draws upon preliminary findings from a small scale study in a children's centre in the UK. To date the research has included participant observation with a shifting group of up to 6 white, primarily middle class mothers and their infants.

I argue that there are three key reasons for the marginalisation of infants within critical geographies and social studies of childhood. First, infants do not ostensibly express the kinds of agency that have been integral to the emergence of critical research about children and youth; it is difficult to 'listen to the voices' of infants. Second, infants' agency can only be understood intersubjectively, as entwined with the socio-spatial context of their lives, most notably of families. Research into the spaces of families within critical social studies of children have been limited in comparison to other spaces, in a reaction against a tendency to subsume children within their families in earlier social research (Holt, 2011). Third, research with infants presents methodological and ethical complexities which cannot easily be addressed within the standard matrices of critical social research about children, and indeed challenges some of the central and accepted conventions.

This paper has five key sections. In the following section, I reflect upon some reasons for the relative absence social studies infants as agents, within the context of the bourgeoning inter/sub-disciplinary field of geographies and social studies of children and youth. Of course, there are some precedents for examining the socio-spaces of infants, which are explored in the third section. The discussion moves on to consider three key, interconnected, potential paths studies of the socio-spaces of infants, drawing upon a small ethnographic study of infants with their carers in a children's centre. The three avenues to explore are: parent/carer infants and micro-mobilities; moral geographies of specific infant/ parent/carer focused spaces; micro-infant geographies, infant agency/subjectivity and subjectification in specific spaces and times; broader socio-economic

4 The relative lack of dialogue between researchers of children and youth and those of families is beginning to be addressed - partly by such activities as the International Conferences of Geographies of Children, Youth and Families and other recent symposia, (e.g. Interdisciplinary perspectives of family life, 2008; Holloway, 2007; see also Valentine, 2008), along with the activities of professional bodies such as the CGYF Study Group of the RGS/IBG. 
inequalities reproduced in infant subjectivities : habitus. The penultimate section discusses some of the methodological and ethical complexities of researching with infants, and questions how (and if) these can be overcome. The final section offers a conclusion.

\section{Why are infants as agents largely absent from geographical and social stud- ies of childhood, and does it matter?}

The emergence of the sub/inter-disciplinary field of geographies of children and youth has led to a significant growth in awareness and scholarship about the spaces and spatiality of young people (see Holt, 2011; Hopkins, 2013; Skelton, 2016). However, to date, the sub-discipline, and by extension geography and critical social studies of childhood more broadly, has tended to neglect the experiences of infants, and indeed very young children.

A key focus of geographical research about children and youth is those in the 'middle years of childhood.' Overcoming the tendency to overlook this group has been a pivotal element of the social studies of childhood (James et al., 1998). Accounts of older young people have also continued apace. A very small number of studies have attempted to engage with very young children as agents (Gallacher, 2005; Horton; Kraftl, 2010; Hancock; Gillen, 2007). There are very few studies which have sought to explore the agencies of infants, although see Tebet (2014).

The recasting of children as agents has been central to the emergence of geographical and social scholarship about young people (Holloway et al, 2018). Arguably, however, the centrality of seeking children's agency within geographical and social studies of childhood has precluded a serious engagement with infants; infants do not express the kinds of independent agency which underpin the research approaches adopted in this inter/sub-discipline. It is impossible to 'listen' to 'infants' voices in a straightforward manner, as they generally cannot talk. Arguably, infants would not respond well to the participatory, child-centred methods which have been central critical social and geographical studies of children. In relation to toddlers, Gallacher (2005: 243) claims that:

"early childhood has been somewhat neglected, perhaps due to 'our' general underestimation of the abilities and social competence of young children and the perceived methodological difficulties in engaging with them".

I would further argue that, although infants have agency, they do not express the kinds of autonomous, sovereign, independent agency which has been 
implicitly adopted in geographical and social studies of children. Thus, to engage with infants, geographers researching children and young people must continue the project of deconstructing the notions of agency adopted, to more fully explore how all agents only become through inter-subjective relations of physical and emotional interdependence in space (see for instance Butler, 2004), while still continuing to retain a notion of agency, which is central to the political project of researching with children and other groups whose voices and perspectives are so often sidelined (Holloway et al., 2018). Further, researching with infants presents challenges which can only be overcome by deconstructing the standard, and increasingly orthodox, methodological-ethical matrixes of researching with children, which are in turn underpinned by liberal notions of agents. In short then, researching infants might require unravelling some of the central tenets of how geographers and social scientists have gone about researching children.

The relative absence of infants within geography is both surprising and problematic, given the importance placed on the pre-school age group in theories of child development, critical accounts of social reproduction and psychoanalytical approaches. The limited scholarship about infants in geography is reflected in the broader social sciences (Brownlie and Leith, 2011; Tebet, 2014). Infanthood and early childhood is viewed as the pivotal period in which an individual's capacity to learn is largely established (Shonkoff; Phillips, 2000; Halfon et al., 2001; Campbell et al., 2014), their classed dispositions are embodied (Bourdieu; Thompson, 1991) and their personality, mental (ill-) health and wellbeing and/ or anxieties and neuroses are laid down. Attachments in infancy are viewed as key to socio-emotional relationships throughout the lifecourse (Bowlby, 1969), although they are increasingly accepted as malleable throughout the lifecourse (Stern, 2006). As a result of the limited engagement from critical social scientists and geographers, very early childhood remains largely the domain of child development psychologists. Since children's geographies and social studies of childhood are premised on the need to challenge these accounts by foregrounding the social and spatial construction of childhood and the lived agency of children, it is problematic that we have been content to leave this important domain to psychology, cognitive theory and theories of attachment.

Although the static views of later life implicit in suggestions about the importance of infanthood can be challenged; our bodies and minds continue to evolve throughout life (Shilling, 2012; Bondi, 2005), infanthood is arguably a uniquely dynamic learning phase in a person's life. Classed, racialized, gendered, and sexualized identities begin to be laid down during this period of our lives, in ways that are not easily transformed later. Investigating infants can give crucial insight into 
processes of subjectification; how society and nature intersects and combines in embodied identities, and therefore how societal inequalities are reproduced or can be transformed. The marginalisation of infants in academic studies also reproduces the liminal position of infants and their primary carers in broader society. The lack of critical social and geographical studies of infants' (inter)subjectivities also means that knowledges about these early states of childhood continue to be captured by the very types of developmental understandings of childhood which critical scholars of children have critiqued and moved away from.

Lack of understanding about the socio-spatial context of infancy means that norms of early childhood that have emerged in specific contexts, then become expectations of childhood developmental progress. This is a governmental process (see Rose, 1990) whereby common sense and scientific 'knowledges' coalesce and are taken as the truth. Norms which emerge as an average in specific, often in experimental and decontextualized settings become applied as an expectation for development. These categorise and label as abnormal those children who fall below these expectations (Gallacher, 2018), which actually, if a norm is just an average, a certain percentage should fall below, along with above, the norm (Foucault, 2004; Canguilhem, 1973; Philo, 2007).

\section{Precedents for examining infant geographies:}

Although infants as agents have not been a central concern for geographers, there are some precedents for examining geographies of infants. Here I focus on three of these: a small number of studies of young children (although not specifically infants); feminist approaches to child caring and the family; and, psychoanalytical geographies.

A small number of studies of young children (although not specifically infants) have been published within geography; key here are Gallacher (2005), Hancock and Gillen (2007), and Horton and Kraftl (2010). Gallacher (2005) uses a Foucauldian approach to explore the power-relations between children of around two years old and nursery workers in a formal child care setting. Hancock and Gillen (2007) present findings from an in-depth ethnographic study of three two year olds in their homes in diverse geographical contexts (a small Midwestern US town, a large northern city in Italy and a small mountain village in Peru). Horton and Kraftl (2010) explore the experience of Sure Start Centres by young children (aged approximately three to four). Although exploring the geographies of toddlers rather than infants, these three studies provide methodological and conceptual insights for investigating infant geographies. 
Infants have been present within certain sub-disciplines of geography, notably feminist studies and population research. Here infants tend to be constructed as 'objects of care' (e.g. in feminist research) and/or 'objects of analyses' (e.g. within population geography). This clearly reflects the early position of children more generally within these strands of geographical research (Holloway; Valentine, 2000). Conceptualisations of children and childhood have been challenged and transformed within geography, including in those sub-disciplines previously critiqued for treating children as objects, such as feminist and population geography (e.g. Holloway et al., 2018; Van Blerk; Ansell, 2006; Bushin, 2009). Indeed, as Holloway (2014) points out there are many connections between feminist geography and geographies of children and youth. However, constructions of infants specifically have been largely uncontested.

The most significant existent geographical literature about infants is broadly feminist studies of child-caring and the family. Feminist geographers initially responded to the emphasis on masculinist 'public' concerns in geography which reproduced dominant discourses of child-caring as naturally private and feminine by exploring the social geographies of child bearing, raring and caring (among other concerns) (Peak, 2017). Infants have featured prominently in feminist studies, as they require a great deal of care, which is usually delivered by women - with significant impacts upon their everyday lives, and trajectories in paid careers (England, 1996). A high proportion of feminist studies of children continue to focus, rather paradoxically, on the 'public' space of non-parental child-care (e.g. Vincent et al., 2004; Boyer et al., 2013; Gallagher, 2013). Feminists geographies have, however, increasingly explored a variety of concerns, such as the interconnections between paid and unpaid caring and other work (e.g. Pratt; Yeoh, 2003; Pratt, 2004; McDowell et al., 2005), the reproduction and transformation of gendered moral geographies of parenting (e.g. Holloway, 1988; Duncan et al., 2004; Duncan; Smith, 2002; Duncan, 2005) and the intersections of everyday geographies of caring with the (global) economy (Dyck, 2005; McDowell et al., 2005). Feminist geographers have also investigated the gendered moral geographies of breastfeeding (Pain et al., 2001; Boyer et al., 2013; Boyer, 2011; Grant, 2016), engaging with critical social science scholarship (Faircloth, 2013).

Despite the insights of these studies, seldom is the agency of infants fully explored. Rather, infants and children are represented as burdens of care; they are of interest only because they require caring 'work', usually delivered disproportionately by women. A side effect of the lack of consideration of the specificity of infants' agency is that these geographies have generally not fully explored 
the emotional entanglements of parenting - the joys along with the frustrations and the effort required.

Recently, feminist geographers have begun to more fully explore the emotional geographies of parenting and 'doing family' with infants (e.g. Aitken, 2000, 2009; Gabb, 2004; Lupton, 2013; Horton; Kraftl, 2009a; Madge and Connor, 2005). Parents and children have intersubjective relationships based upon reciprocal ties of emotional inter-dependency - albeit shot through with unequal relations of power between parents and children, between parents, and between parents and broader society. Infants and young children are intersubjective agents in these emotionally co-dependent relationships. Parents, like infants, are constituted and 'become' subjects through these relationships (Madge; Connor, 2005). Although the agency of infants has not been a specific focus of these accounts, studies of the intersubjective, affective relationships between parents and children, including infants, hints at the importance of infants as agents. Consider for instance Stuart Aitken's (2000) son Ross, who refused to be pacified in the usual way in the public space of a family gathering, leading to a female relative casting Aitken as an incompetent carer for being male. Infants are also increasingly present in accounts of parenting with babies and/or birth, although often more for the way they transform the social spaces of the mother than for the ways in which their subjectivities are emerging (Longhurst, 2008, 2009; Gabb, 2004; Mansfield, 2008). Infant geographies could build upon these accounts by focusing more specifically on the agency of infants.

A second precedent for exploring infant geographies is psychoanalytical approaches. Infants are figuratively present in psychoanalytical accounts, particularly those that critically engage with object-relations theories (e.g. Philo; Parr, 2003; Kingsbury; Pile, 2014) Object-relations theories prioritize early infancy as the pivotal stage of subjectification of individuals, from which personal characteristics and neurosis stem. Particular emphasis is placed on the moment of psychic separation from the (m)other, at around 6 months, when infants begin to realize that they are an independent person:

...the child gradually develops a sense of itself, initially as a result of its gradual realisation that it has a separate body from its mother. The child's self is constructed as a relationship between self and other objects, such that the boundaries between the self and the external world become increasingly well demarcated, but where the child's sense of self (or ego) is always mediated through its relationship to objects (Pile, 1996: 90). 
Crucially, most psychoanalytical geographers emphasise that the subconscious is not bounded or separate from the social, but that these boundaries are tied to specific spatial contexts (Aitken; Herman, 1997; Bondi, 2014). Despite the importance of infanthood to psychoanalytical geographies (although compare Bondi, 2005), there is a dearth of empirical geographies that have sought to unravel how these processes of subjectification take place in actual infanthoods. Rather the emphasis is on retrieving adults' inner infant selves (Bingley, 2003). Implicitly, however, the emphasis of infanthood within these psychoanalytical accounts points to an agenda for investigating how subjects are formed in early childhood (Aitken, 2001).

The potential of infant geographies inherent in psychoanalytical approaches to geography is implicitly developed in the work of Aitken (2001) and Aitken and Herman (1997) $)^{5}$. These have proved extremely influential texts in the emergence of research into the lives and experiences of children and youth. The critical engagement of Aitken and Herman (1997) with Winnicott presents an agenda for researching infant geographies on three interconnected grounds: first, the focus of early childhood in Winnicott's psychoanalytical theory; second Aitken and Herman's emphasis on transitional spaces which emerge in early childhood; and third the substantive examples in the paper, which are primarily drawn from early childhood.

In common with other object-relations theorists, Winnicott focuses upon the moment of psychic separation from the mother in infancy as pivotal to the development of subjectivity. (Importantly Aitken and Herman point out that although Winnicott reproduces gender exclusivity in his object-relations theory, the arguments can be applied to any primary care giver.) Winnicott's thesis of this process is inherently less negative than many other psychoanalytical theories (see also Bowlby, 1969). Rather than generating ontological insecurity, Winnicott suggests that the secure child who has had a 'good enough' mother (or carers) experiences the realisation of their separateness from their (m)other as a kind of adventure:

...According to Winnicott, the process is the creation of a self different from but in relation (rather than in opposition) to an other. Unlike Freud or Lacan, Winnicott believes that separation between the child and their external environment is generated by the child's own need for knowledge.

$5 \mathrm{Kraftl}$, and Horton, 2008, also implicitly suggests an agenda for researching baby geographies. Their discussion of the geographies of children's sleep is implicitly a geography of infants and young children who are the primary targets of such 'sleep training'. 
For Winnicott, unlike Lacan and Freud, separation is not necessarily painful or a blow to the infant's narcissism or illusion of omnipotence. Rather, it is characterized as a transition into a productive period of self-realization (Aitken; Herman, 1997: 73, emphasis added).

Aitken and Herman's key argument draws out the parallels between Winnicott's notion of transitional space, which emerges through (or rather between) processes of individualisation and separation, and conceptualisations of the socio-culturally constructed nature of space. They highlight the importance of play(ing) with culture in Winnicott's account of transitional space, which emphasizes instability rather than the reproduction of fixed identity categories - prefiguring post-modern concerns (see also Katz, 2004, for a discussion of mimesis, which has similar potentialities).

By focusing upon Winnicott's object-relations theory, with its emphasis on early childhood, Aitken and Herman point to the importance of infanthood in the emergence of a subject. The substantive examples on which they draw are primarily from early childhood - from the 'crib' in the title to the 'bunnies' and 'security blankets' which are part of the "transitional space because they are the first area of experience that is neither self nor mother" (Aitken; Herman, 1997: 74). Arguably, then, Aitken and Herman's children's geographies is substantively the geography of early childhood, although the theoretical account has widereaching resonance. Whereas their theories have been highly influential within geography (see also Aitken, 2001), the implicit call for studies of early childhood has largely not been taken-up. Winnicott's theories of objection-relations have parallels and commonalities of emergence with attachment theories, which are discussed in the subsequent section.

\section{Fruifful avenues for infant geographies}

In the sections below, I outline three potential foci for exploring infant geographies. This is clearly not an exhaustive list; rather it is one suggestion for possible research agendas.

\subsection{Everyday geographies of infants and parents/carers}

There is significant scope for geographers to explore the everyday spaces of infants, which have been neglected within geographical studies. Here I outline two key potential avenues for explorations of everyday geographies of infants and parents/carers, the socio-spatial movements of parent-infants and privileged 
infant-parent spaces, although of course there are other places and spaces in which, through which and by which, infants' and parents' subjectivities are coconstructed. Because infants largely cannot move through space independently, and since their agency is so evidently interdependent with their carers, I use the terms infant-carer or infant-parent to suggest the co-construction of the emerging subjectivities of infants, parents and/or carers (see Section 4.2).

\section{1.i Parent/carer infants and micro-mobilities}

This seems an obvious place to start exploring infant geographies; the problems of moving through spaces essentially not designed with the infant-parent/ carer subject in mind (Greed, 2003). The town becomes coded differently for parents and carers with infants, with routes through the town marked by: paths that are stroller-friendly (which parallel the experiences of wheelchair users in being circuitous); the cleanest place to change a nappy; where an infant can be breastfed comfortably; and later, where infant's food can be heated up. There are clear parallels here to feminist time-space geographies (e.g. Tivers, 1985; Jarvis et al., 2013; Bowlby, 1990) and disability geographies (e.g. Matthews; Vujakovick, 1995).

These everyday geographies of moving through space include socio-cultural along with physical elements (Imrie, 2014). To paraphrase Kitchin (1998) places are coded to keep infant-parent/carers in their place (see also Cresswell, 1996). Campbell (2009) highlights how society and space is designed around a norm of an able body and mind, which disables by comparison those whose bodies fall outside of these norms. Like those with mind-body-emotional differences, infants and carers are dis-abled by their inability to move through the environment freely, by their multiple deviations and the need for stops, and by being unable to negotiate steps, small doors and so on. From a socio-cultural perspective - what message is conveyed by infant changing rooms often being in the disabled toilet (see also Kitchin; Law, 2001; Hall; Wilson, 2016), or spaces to sit and breastfeed being within an infant changing facility? How do 'gazes' and social expectations of normative behaviour reproduce the marginalisation of infants-parents/carers, particularly breastfeeding mothers (see also Boyer, 2011, Grant, 2016). It is interesting to note that over time parents can become desensitized to subtle, negative glances with all but the most obvious negative responses becoming invisible. It is also intriguing to note that these experiences of parents and infants being marginalised in space are socio-spatially specific, and will differ significantly in different times and spaces. More comparative work is required about these concerns. 
The individual agency of infants, as interpreted by parents/carers, influences how infants-parents/carers move through space. Infants have different responses to, for instance, how happy they are to wear a dirty nappy for a short period and whether they are fairly relaxed about when they get their lunch. Of course, an infant is dependent upon her/his parent/carer responding to her/ his 'requests' such as for food or a change of nappy. However, once an infant is demanding something, by crying loudly, not responding to their request is difficult. Parent-infants become subject to sustained variably negative to understanding glances if the infant is making loud noises in public places. In the most extreme examples, when parent-infants have not responded to more subtle glances, they can be actively excluded from specific spaces (Grant, 2016).

\section{1.ii Moral geographies of specific infant/parent/carer focused spaces}

In common with disabled and/or gay, lesbian, bisexual and trans-gendered people, parents, especially of younger infants, often need to forge a space of acceptance and inclusion in the face of being socio-spatially constrained within society. This is arguably particularly true of mothers who work exclusively in the home and/or are on maternity leave and/or those who are breastfeeding.

Groups of breastfeeding mothers take up positions in public spaces, such as cafes, and support each other in contesting dominant expectations by breastfeeding in public. Parents (especially mothers) might visit each others' homes - particularly when male partners are not present. Also, organized activities provide social spaces wherein infants begin to socialize with others and in which parents, particularly mothers, develop social networks to share knowledges and experiences. These are exclusive spaces, which can only be entered by parents/ carers, infants and the facilitators or organizers.

Although these parent-infant spaces can feel like relatively bounded, specific places, distinct from broader socio-spatial impulses, these are clearly specific moments in broader socio-spatial networks. In particular, they are influenced by social policy imperatives. In the UK, the very existence of some of these specific spaces (e.g. Sure Start Children's Centres) is tied to policy imperatives to provide a greater level of state support/intervention into particularly working class / socially excluded children's lives (Horton; Kraftl, 2009a, b; Jupp, 2013). These spaces have since been radically transformed as Austerity measures have led to closures, the reduction in services and facilities, and the increasing targeting of facilities in Children's Centres, which have disproportionately affected poorer families (Ridge, 2013). 
Further, these spaces are primarily mother-infant spaces, and this is influenced by the maternity leave to which many employed women in the UK are entitled $^{6}$. This maternity leave is welcome and helps women to combine a paid career and family life. Clearly, the leave could be more highly paid. Moreover, maternity leave is underpinned by the naturalisation of women as the most suitable carers of young infants. In the UK the leave cannot currently be shared by partners?

These parent-infant spaces are arenas in which particular moral geographies of parenting are reproduced (Holloway, 1998a, b; Duncan et al., 2003; Duncan et al., 2004; Duncan; Smith, 2002; Duncan, 2005). Discussions among middle class mothers in these groups were often framed around four key concerns sleeping, nutrition, child development and the return to paid work. The relative importance of each shifted over different time periods and was often framed by the age of infants and the 'stage' that they were perceived to have reached. In the following excerpt, many of the mothers were weaning their infants, about which they compared notes:

... the discussion moves back to the favourite topic of the time - weaning infants, and what food infants had tried. Notes are compared and ideas swapped on food the mums have cooked for the infants. There is a hint of competition as the mums discuss the adventurous, exotic and often relatively expensive recipes they have created (with ingredients such as avocado, sweet potato, guava and mango). Then Jane, a nurse announces: 'I don't cook for Jemima - my god I've got enough to do. She eats jars [of food]' The mums look a little taken aback, and there is a short silence before Carry says, yes, I've been giving Beth jars recently, because we are going away, and I wanted her to get used to jars before we went. Another mum joins in 'I give (my baby) jars when I am out, some cafes won't heat up home-cooked food (Research diary extract, Children's Centre Group).

Infants begin to be subjectified in particular ways in these spaces, and clearly this is connected to the types of moral geographies of parenting reproduced. Of course, infants are subjectified in all the spaces through which they move, and

6 In the UK context most employed parents are entitled to take leave, which can be shared between a mother and a father, with a total of 52 weeks, the first two weeks of which must be taken by the mother. Some of this leave is paid for 9 months maternity leave, which is at a gradated level of pay (moving from $90 \%$ salary for $6 £ 136.78$, or 90 per cent of your average weekly earnings, whichever rate is lower). In addition, some employers (particularly of professional women) enhance maternity pay. Same sex and adopting couples have the same rights. 
the knowledges reproduced in parent-infant spaces permeate into the home, which is a porous space rather than a bounded place (Wood; Beck, 1994). Studies of infant-parent micro-geographies in the home would also be a particularly fruitful avenue for research, given the limited amount of research that is currently conducted in the home. However, there is no necessary association with familial social relations and home spaces - clearly families interact in a variety of spaces. There is also scope for researching infant geographies within the everyday spaces of childcare (see Gallacher, 2005; Horton; Kraftl, 2009a, 2010). However, infant-parent/carer geographies are neglected by comparison to the formal spaces of childcare, and this warrants further attention (see Cortes-Morales; Christensen, 2014).

\section{2.iii Micro-infant geographies, infant agency/subjectivity and subjectification in specific spaces and times}

Infants cannot communicate their agency verbally or via the 'participatory methods' that children's geographers have commonly employed. Nonetheless, any parent knows that their infant is a unique individual from the moment they are born (or possibly before). Infants are able to affect change in their worlds, although this ability is dependent upon the response of others around them.

The agency of infants can only be understood as inter-subjective with their parents/carers within specific socio-spatial contexts. Infants clearly cannot be understood as sovereign, independent agents; their ability to affect change is contingent upon the appropriate interpretation of their wishes by carers and eliciting a response. Rather than infants as agents, perhaps it is fruitful to explore the infant-parent/carer-nexus; the intersubjective relationships between infants, parents-carers/others, in socio-spatial context.

Clearly, this conceptualisation of infant-parent/carer-nexus dovetails with recent challenges to representations of independent agency within social sciences (e.g. Ruddick, $2007 \mathrm{~b}$ ). There has been a growing awareness from a variety of perspectives that the independent agent does not exist. It is increasingly accepted in geographical research, that agency emerges in specific contexts from a particular constellation of material and immaterial co-presences (Bondi, 2005; Anderson and Wylie, 2009). ${ }^{8}$ All individuals are co-dependent in both physical and emotional senses (Butler, 2004). Infants, with their high level of physical dependency clearly demonstrate this inter-dependence. Further, in order to

8 I would, however, concur with many geographers who believe, often implicitly, that individuals become specific agents with continuities that endure between spaces and times, and are not endlessly fluid and dynamic. 
thrive, infants need love and affection; it is insufficient for just their physical needs to be met.

Although unequal, the relationship between infants and parents/carers is not unidirectional. Parents/carers often gain immense fulfilment, emotional satisfaction, and a feeling of emotional reciprocity from infants (which motivates them to cope with the sleepless nights and emotional and physical exhaustion of early parenthood) ${ }^{9}$. I do not want to over-emphasize the positive emotions of early parenthood - clearly there are also frustrations and many parents at some points feel emotionally over-whelmed and under-responsive (or exhausted). What I do, importantly, want to express is that infants bring something to the relationship, they give something back.

The relationships between infants, their parents/carers and the social contexts in which they live, are shot-through with power relations, and the need for emotional recognition is a component of the emergence of power (Butler, 2004). Parents/ carers have much power over infants as infants are physically and emotionally dependent, as becomes only too obvious in horrific child abuse cases. Infants express most pertinently the corporeal vulnerability of humans (Harrison, 2008). However, in contemporary western societies, where childbirth is a specific, rather than commonplace, life event, infants completely transform and disrupt the lives of carers/parents.

Everyday infant geographies can provide a unique insight into how the processes of subjectification - or the internalisation of normative power implicit in the very construction of individuals as subject/agents - occur in specific spaces. From our earliest moments of life, we are subjectified and placed within matrices of appropriate personhood. Judith Butler (1997) suggests that at the moment of birth, to become a person, the infant is sexed. As Butler states, on being informed of the birth of an infant, the first question asked is usually 'what is it?'. We all know what is meant by the question, what is it? (The answer is, he is a boy or she is a girl). Increasingly, the ascribing of sex and the beginnings of subjectification, occurs before birth. The ascribing of agency to the foetus who cannot talk reminds us of the dangers of ventriloquism (see also Ruddick, 2007a, b). Further, the personification of the foetus begs questions about what is and what is not human, and/or a viable agent.

9 Of course this is not the experience of all parents all the time. Some parents (particularly although not exclusively mothers) find early parenting a time of deep despair, depression and/or find that they do not feel for their infants the sense of unconditional love they are expected to feel. Of course, these are often symptoms of post-natal depression. However, most parents feel some negative emotions at some stage of early parenting. 
Observing the subjectification of infants within their earliest micro-spaces might provide insights into how the dynamic biological and social intertwine in constructing the subject/agent in particular socio-spatial contexts. Early childhood provides a unique opportunity to explore how these processes of subjectification occur, particularly given the importance placed on infancy in the embodiment of the norms and values of societies. In the extract below, the gendered subjectification of infants continues in the everyday practices of parents and infants. The relative importance of parental practices and infants' specific subjectivity or agency is unclear:

... the mums are sitting in a loose circle, with the infants in between. There are three female infants (Harriet, Jessica and Charlotte) and three male infants (Peter, Paul and Jack) - all infants are around 7-8 months. Paul is very active, compared to the other infants, and is crawling around. He crawls away from his mum. Jack is rolling, away from his mum. Harriet and Charlotte are sitting close to their mums. Jessica is sitting a little further away from her mum. Peter is also sitting close to his mum. The mums periodically kiss and cuddle their infants. With the exception of Peter, the infant girls get more affection than the boys. I am not sure if this is because the boys are more active, or maybe the boys are more active because their mums prioritize independence. (Earlier Paul's mum said that he isn't a very cuddly infant). (Research diary extract, Children's Centre group).

Judith Butler (1997) explores the concept of subjectification from a variety of philosophical perspectives. Notable here is the intertwining of Foucault's theories of subjectification with post-Freudian object-relations theory in an endeavour to unravel the mechanisms of how normative power is internalized within psyches. Butler takes as a starting point Foucault's (1978) critique of the idea of a pre-social, interior and socially anterior psyche.

This is an important point which destabilizes universalist conceptions of the psyche, and suggests how subjectification becomes embodied. We do not (usually) consciously act appropriate subject positions; rather appropriate identity performances become embodied as natural. Geographical accounts that have drawn upon psychoanalytic theory have generally theorized the psyche as framed within social and cultural relations (e.g. Bondi, 2014; Kingsbury; Pile, 2014; Philo; Parr, 2003).

Callard (2003), however, critiques the tendency of geographers (and by extension other social theorists) to side-step that the: “... unconscious throws up 
large, intractable obstacles in the path of the hoped-for achievement of subjective transformation." (Callard, 2003: 305). Although the idea of any realm of psychic life as pre-social is problematic (as this would arguably lead to universalist understandings of the psyche), I would suggest that surely the purpose of social theorists (or philosophers) delving into psychoanalysis must be to understand how the beyond-conscious aspects of minds are less open to transformation than the consciousness (see also Butler, 1997).

Observing my infants has led me to question the Foucauldian-Butlerean position that there is no interior or socially anterior psyche. Perhaps there is no internal psyche that can be understood outside of the socio-cultural matrices of specific spatial and historical contexts. Perhaps the specificities of individuals emerge from their social contexts. Each of my children was unique individual, even in utero - and this might be that they are a specific coming together of matter that comes together in specific ways, with bodies, like individual places, specific moments in space/time at a micro-scale - a specific mass of chemicals, microbes, cells, micro-fauna, and so on. Perhaps there is a more existential spiritual explanation. I would further argue that an implicit belief in the uniqueness of individuals is inherent in many accounts of agency and social transformation. The problem might be, therefore how to negotiate the uniqueness of the transformative agent without recourse to modernist, liberal notions of agency (see Holt, 2013).

In emphasising the formation of the subject/agent in power as ontologically connected to others emotionally and physically, Butler (2004) emphasises the importance of relatively positive socio-psychic processes of 'recognition', which I have discussed in more detail elsewhere (Holt, 2009; Holt et al., 2013). This stands in contrast to more masculinist and oppositional versions of the psychic formation of the subject, such as in object relations theories, where the self is produced in contrast to an (abjected) other (see also Bondi 2002). This formation of subjects within power through positive processes of recognition dovetails with Foucauldian concepts of power as ontologically generative, formative of the subject who can act (Foucault, 1979). Therefore the person is formed within power, and agency is also formed within the contexts of subjection - a genesis which can be exceeded through never fully escaped (Butler, 1997) - although of course the 'contexts' of power are dynamic and shift in space and time (see Holt, 2013, for further development of these ideas).

Butler's theories of subjection have the potential to be explored in critical dialogue with attachment theories to examine the emergence of subjects within specific 'conditions' of attachment. Although seldom discussed (and possibly 
implicitly rejected) in human geography and critical studies of childhood, the importance of John Bowlby, Mary Ainsworth and colleagues' theories of attachment to early childhood studies and social policies of early childhood cannot be over stated (Bowlby, 1969, 1979, 2005; Ainsworth 1967, 1968, 1982). Attachment theory developed in dialogue with Winnicott's notions of socio-psyche development, and John Bowlby and Donald Winnicott corresponded (Bretheron, 1992). Attachment theory is inherently a more positive view of socialpsyche development than object-relations theories, given the importance given to intersubjective relationships of emotional interdependence as a requirement for emotional and social development of children. Attachment theory is an approach that emerged from a dialogue between psychoanalytical and psychological approaches and prioritises infant-maternal relations (Hollway, 2006). Attachment has only recently gained more influence within psychoanalytical theory (Schwartz, 2007).

Attachment theory has some useful insights for geographers and critical social scientists of young children, and I argue that it is imperative that critical social scientists engage with the accepted paradigms within early childhood development and social work and social policy literature in order to both critique and sophisticate these fields, which are disproportionately influential in policy arenas. Both Winnicott's object-relations theories and attachment theory focus upon substantive maternal-infant relations within specific socio-spatial contexts, rather than clinical psychoanalytical settings (in direct opposition to Klein, e.g.1984, see also Bick, 1964, 1969; Freud, 1954). These approaches provide potential important starting points for geographies of infants. Attachment theories differ from Winnicott's object-relations by emphasising relations of attachment rather than psychic self-differentiation, providing a relatively positive account of psychic development (see also Bondi, 2005, from a different perspective).

There is perhaps good reason why critical social scholars have avoided Bowlby's attachment theory (see Hollway, 2006). It has a troubled relationship with feminism, as this work has been used to suggest that women should be the primary care givers of young children (e.g. Barglow et al., 1987). Attachment theory has an implicit biological reductionsim; the theory emerged from ethological studies of animals and an engagement with evolutionary theory along with psychoanalytical and psychological accounts, and emphasises attachment as universal biological survival instinct (Bretherton, 1992). Although Winnicott and Bowlby have proved influential in transforming social policy in contexts ranging from hospitals to social work, to the paid workplace (Bowlby, 2005), their research is often, problematically, used to focus critically and exclusively 
upon not 'good enough' mothering, rather than the role of a range of sociocultural and material factors in the subjection of infants (Jensen; Tyler, 2012). Indeed, it could be argued that attachment theory has a normalising power or becomes a form of governmentality whereby the 'attachments' and emotional relationships of (particularly poorer) families are measured against normative standards of attachment emerging from specific socio-spatial contexts, rather than focusing on the material inequalities between different families (see also Smith, 2014). Further, as Bessell (2016) points out, the 'strange situation' a common measure of attachment (Salter et al., 1978), denies children their basic rights under the United Nations Conventions on the Rights of the Child. It is, however, possible to broaden conceptions of attachment to a variety of caregivers and familial contexts, and there is no necessary association of attachment theory with conservative views (Kenny, 2013).

Importantly, the desire of infants to attach to their carers and others provides a context for understanding individuals' "passionate attachment to subjection" (Butler, 1997: 105). Power is reproduced via nurturing relationships along with conflictual ones. Indeed, ideas of appropriate subjectivity are perhaps (most) effectively reproduced and embodied when infants become healthy, happy, productive subjects. Critical social and geographical studies of infants could draw attention to the particular socio-spatial contexts of infants' emergence, to explore the: 'productive powers put into play through its [the infant's] interconnections and interactions with an array of others, both organic and non-organic' (Shildrick, 2010: 6). This would require in-context sociological or anthropological studies of attachment and subjection, providing methodologies which could overcome the critiques levelled by Bessell (ibid.) and opening up studies of attachment to more fully appreciate the often unequal material and social spaces of infants' emotional development, challenging the normative power of decontextualized measurements of attachment.

\section{3.iv Broader socio-economic inequalities reproduced in infant subjectivities : habitus}

The subjectification of infants places them, from their first moments of life, within 'acceptable' positions in relation to a host of identifiers, including class, gender, sexuality, race and ethnicity. I have elsewhere sought to explore the interconnections between Butler's conceptions of performativity and subjection and Bourdieu's notions of habitus (Holt, 2008).

Infancy is an absent presence in much of the increasing volume of geographical studies which engage with Bourdieu's theories of social reproduction. The 
concept of habitus, in particular, has resonance for investigating infant geographies. Habitus is:

the embodied materialisation of individuals' capitals, or 'internalized capital' (Bourdieu, 1984: 114; Painter, 2001; Shilling, 2013) ... habitus provides an unconscious backdrop to individuals' practices within particular social "fields" (Holt, 2008: 229).

Bourdieu and Thompson (1991) contend that habitus is subconsciously inculcated through processes of mimesis, particularly during early childhood (Butler, 1999, provides further flesh on this account by suggesting a dialogue between performativity and habitus).

Different authors have suggested that habitus is variously dynamic versus enduring and exists at either a group or individual level (compare Smith; Phillips, 2001; Cresswell, 1996). I would argue that habitus is embodied, particularly during early childhood; if we understand bodies as always connected, this does not preclude habitus existing at both the individual and group level. Although open to transformation (as our bodies and minds are not fixed at, for instance, age five) habitus does exhibit a friction to change. It is therefore pertinent to explore how class habitus is 'taught' during earliest childhood. Linda McDowell and colleagues (e.g. McDowell, 2006, 2007; McDowell et al., 2006) demonstrate the potentiality of infant geographies of habitus. Although not focusing specifically upon the agency of children, these studies explore how class habitus is reproduced within middle class families who employ largely working class paid child carers. McDowell (2006) points to the dichotomous class relations between the largely middle class parents who employ paid child carers and the typically working class child care workers. It will be interesting to review how government policy, which reproduces the middle-class norm of the mother as a paid worker, by providing financial support for the costs of childcare to lower income families transform these class relations (Duncan et al., 2004).

The focus on habitus emphasizes that the everyday geographies of infants do not see them move through bounded sites (the home, the nursery, the parent and infant group). Rather these sites are porous and connected to social, cultural and economic impulses emerging from a variety of interconnected spatial scales (see Holt, 2004, 2007; Holt et al., 2017; Holloway; Valentine, 2000; Ansell, 2009; Holloway et al., 2018; Dyck, 2005; Wood; Beck, 1994). These are embodied in the individual and reproduced subconsciously - although this is not a reductive process and there is always a potential for transformation (Holt, 2017). 
The embodiment of capitals as habitus by infants is a fruitful avenue for researchers of infant geographies. Class, class faction and by extension gendered, racialized, sexualized identities are incorporated into material bodies via habitus and it is difficult or impossible to unravel social versus corporeal elements of bodies. How different classed (and class faction) identities, reproduced via various moral economies and/or cultures of parenting, are embodied as habitus in infants is intriguing. Parenting cultures shift in different spaces (Hall, 2016) and this will affect the developing, interconnected corporeality and subjectivity of infants.

Practices around nutrition, feeding and breastfeeding in particular are embodied in infants' corporeality (Holt, 2016). Practices of breastfeeding are reproduced via differential cultures of parenting (Pain et al., 2001). These cultures of parenting have a class and class faction element (Pain et al., 2001), although they are not strictly class reductive. In the excerpt below, two middle class mums discuss breastfeeding. The discussion of breastfeeding was prompted by these mums asking me if I breastfeed my daughter, and my affirmative answer:

No, with my second baby Delia, I just tried to breastfeed for a couple of weeks. But I got mastitis [an infected, inflammation of the breast], and I just had to gave up. The midwives try to force you to breastfeed. I was told that I had to go and see the breastfeeding expert at the hospital. This time I refused to go. I did breastfeed Poppy, but I hated every minute of it. I gave up as soon as I reached that 6 months. (Samantha)

Well I tried to breastfeed, I really did. But I saw how much more settled Poppy was when you put her on formula, and I thought that formula can't be bad for them, can it? I used to cry when I was feeding Emma. So in the end I thought enough is enough, and I gave up. The midwives do try to make you carry on, but I stood my ground. I don't think it can be good for Emma to see me crying when I am breastfeeding, and I think that was worse. But you do feel guilty - the default position is to feel guilty, because you know that breastfeeding is the best for them (Jane). (research diary extract, Children's Centre group).

\section{AV. Approaches and ethics in research with infants}

Within the paper I have alluded to some of the research approaches that could be used to engage with infant-parent/carer geographies. The intractable problem with researching infants is that, although they doubtless have agency, they do not communicate verbally. Most young infants' main form of communication is to cry, and parents/carers have to deduce what they want. As infants age, the range of their communication diversifies; they start to develop different 
cries, they smile, they laugh, they point and wave (and can be taught other signs), they begin to vocalize 'babble' and they begin to form word - sounds. Geographical research with infants can draw lessons from those who have explored the geographies of other non-verbal actors, such as non-verbal disabled people (Bailey et al., 2015) and animals (Buller, 2015). This manoeuvre is not to equate these groups. However, the inclusion of all non-verbal agents in research contributes to ongoing critiques of the idea of the speaking, sovereign, rationally reflective agent, implicit in much social science research (see Lorimer, 2005; Horton; Kraftl, 2006; Davies; Dwyer, 2007).

Research with children and youth in geography has often tended to seek children's participation by focusing upon their competencies to communicate their agency in ways which mirror, while differing from, the capacities of adults. There has been a propensity to assume that agency can be communicated transparently (Gallacher; Gallagher, 2008). For instance, the experiences of individual children are frequently sought via interview or child-centred participatory methods (Van Blerk; Kesby, 2008). Research about children in geography has often reproduced elements of a Modernist, liberal notion of agency in practice, if not in theory $y^{10}$. The reluctance to fully jettison the sovereign, independent agent in much geographical research about young people is couched within the difficulties that social theorists have found in replacing this masculine figure with an effective alternative agent (see for instance McNay's, 1994 critique of Foucault's attempts to reconceptualise agency, which McNay argues has recourse to a liberal notion of the agent, which is also, arguably, somewhat applicable to Butler, 2004).

Research with non-verbal actors is frequently ethnographic in approach, and I would argue that such methodologies are central to researching with infants in their socio-spatial contexts. The limited number of geographical studies that have attempted to grapple with the lives of young children have been primarily ethnographic (e.g. Gallacher, 2005; Hancock; Gillen, 2007; although compare Horton; Kraftl forthcoming a). These accounts have drawn inspiration from early childhood studies and sociology (Abbott; Langston, 2004). Observation, albeit not necessary ethnographic, is the cornerstone of much social and educational research with young children.

Conducting research with infants raises ethical problems which cannot be overcome by the standard ethical repertoires of human geographers. The

10 There is a counter-story to this broad-brush approach, however, with scholars of children at the forefront of developing alternative approaches to research with young people (e.g. Woodyer, 2008; Aitken, 2009) drawing upon a longstanding ethnographic tradition (e.g. Ward, 1977, 1979; Hart, 1979; Katz, 2004). 
modern, liberal independent agent is particularly sedimented into standard approaches to research ethics. Research ethics are increasingly circumscribed by the pseudo-legalistic framework of ethics committees, and Anglo-American law is designed around a modern, liberal, sovereign agent (Butler, 2004). Dyer and Demerrit (2009) emphasize that Ethics Committees have little dialogue with critical notions of ethics emerging from geography and the social sciences.

A pertinent ethical question is the extent to which adult researchers can ever really apprehend the lives and worlds of infants. The mere action of representing infants' lives involves interpreting infants' everyday practices within adult discursive frameworks, which are, presumably, meaningless to infants. The question remains, therefore, how can the researcher avoid acts of ventriloquism when interpreting the actions of infants? It is impossible to triangulate observations with infants' reflexive discussion of their actions. The interpretation of parents/carers and other significant relations of infants could be sought as a comparison to ethnographers' observations. This is not to suggest that adults can transparently speak for infants, rather significant adults can aid the researcher to interpret the infant's communication (see also Hall; Kearns, 2001 in relation to researching with adults with learning disabilities).

Consent is now a key element of conducting ethical research with children. Geographers would not consider conducting researching with young people without assuring demonstrable full, active consent to research (Alderson; Morrow, 2004). Clearly, it is essential that individuals are not coerced into participating in research, and/or that adult researchers do not otherwise abuse their relatively powerful position in relation to child research participants. However, the concept of gaining active consent can exclude many groups from research (Cocks, 2005). Questions are raised about whether it is ever ethical to research with those who cannot actively consent, or is it more unethical to exclude such groups from research? Researchers of young and/or disabled children have recast the issue of consent as an ongoing interpretive and reflexive process (Cocks, 2005). Similarly, in influential ethnographic studies of children and young people, such as Hart (1979), Ward (1977, 1979) and Katz (2004) consent was approached, as an ongoing process rather than a formulaic procedure. A now conventional approach to gaining written active consent would, no doubt, have been stultifying to these studies which are, overall, empowering to children and young people.

It appears inconceivable that infants can understand that they are participating in research. Infants, therefore clearly cannot even assent to participating in research. Legally, parents can consent on behalf of infants to medical care (which is used as a proxy for inclusion in research, Alderson and Morrow, 2004). 
It is interesting to note that I had fewer problems passing this infant geographies project through the Ethics Committee than researching seeking the active consent of young people. Researching infants in their socio-spatial contexts can begin to answer (and raise) important questions about process of reproduction and transformation of enduring socio-spatial inequalities. Is it therefore ethical to research with infants in ways which do not directly impact upon their lives? Studies that treat infants of objects of analysis, such as the Millennium Project, do not have such qualms about informed consent.

\section{Conclusion}

In this paper I have begun to establish an agenda for exploring the geographies of infants and their parents/carers. Although inspired by existing work in both geographies of childhood and youth and feminism, these substantive geographies of infants are distinct in foregrounding the intersubjective agency/ subjectivity of infants in their socio-spatial contexts, which has the potential to highlight how social reproduction and transformation occurs in the earliest stages of life through subjection. By focusing upon the importance of infant spaces in accounts of subjectification, I run the risk of reproducing a conception of social reproduction as fixed in early childhood. This is not my intention. Rather, I aim to highlight the specific importance of earliest childhood in accounts of subjectification, of social reproduction, and transformation. The lack of studies of infanthood means that geographers have largely not explored this very specific moment in the formation of subjects. The earliest phases of life are crucial to subjection, and the inculcation of norms and values which might later seem 'natural' may be imbedded in the beyond conscious realm, or at least as habitual. Therefore this earliest phase of life is an important arena for understanding the inculcation (and transformation) of norms and values, and the implications for with the (re)production of enduring socio-spatial inequalities. However, this is not to suggest that earliest childhood is the only moment of subjectification. Of course embodied social and cultural relations are transformed throughout our lives (Bondi, 2005). Nonetheless I would argue that the norms and values embodied in infancy are incorporated into our psyche and are difficult to transform. It is imperative that critical social and cultural geographers maintain a belief in the possibility of social transformation, and our empirical observations give substance to this belief. A sensitivity to how normative power is embodied in the formation of subjects in earliest childhood can give an insight into both this endurance, and how transformation can be 
achieved. It is also crucial that knowledge about early childhood is informed by critical social and geographical perspectives, to challenge the classed and ethnocentric governmental power of normalising discourses of childhood development which under-examine the socio-spatial contexts and material differences of early childhood contexts.

My concern with infant geographies is clearly framed by my largely positive experience as a first time mother, situated as it is within particular sociocultural and economic frameworks, as a white, relatively wealthy, non-disabled British woman. There are clearly many different geographies of infants that could be written. Although an interest in subjectification could be transferred to many contexts, the ways in which processes of subjectification occur and the norms, values and lines of inequalities (re)produced and transformed would vary significantly in different geographical and social contexts. Indeed, in some contexts, globally, examining social, cultural and spatial contexts of infants' emergence might be closely tied to very stark issues of life expectancy and infant mortality, morbidity and health, demonstrating the vastly different material realities for children growing up in different contexts (see also Katz, 2017). It is crucial that we understand these context to feed into enduring normative expectations of attachment and development and to destabilise the decontextualized norms when are then applied universally and often inappropriately to childhoods, development, and families.

There is a danger that examining the inevitably intimate spaces of infants becomes so micro-scale in its focus that it is esoteric. To challenge this, risk it is crucial to develop 'counter topographies' (Katz, 2001) of the socio-spatial contexts of infants, to examine "the connectedness of vastly different places... which reproduce themselves differently amidst...common political-economic and sociocultural processes" (Katz, 2001: 1299). These counter-topographies involve collaborative working with scholars from across the globe to connect the microspatialities of infants in specific places with broader global processes, such as global health initiatives and the continuing power of global infant feeding companies.

\section{References}

ABBOTT, Lesley; LANGSTON, Ann. Birth to three matters: supporting the framework of effective practice. Maidenhead: Open University Press, 2005.

AINSWORTH, Mary Dinsmore Salter. Object relations, dependency, and attachment: A theoretical review of the infant-mother relationship. Child development, v. 40, n. 4, pp. 969-1025, 1969. 
AINSWORTH, Mary Dinsmore Salter; BLEHAR, Mary; WATERS, Everett et al. Patterns of attachment: A psychological study of the strange situation. Oxon, UK: Psychology Press, 1978.

AITKEN, Stuart. The awkward spaces of fathering. Aldershot: Ashgate, 2009.

AITKEN, Stuart; HERMAN, Thomas. Gender, power and crib geography: transitional spaces and potential places. Gender, Place and Culture: A Journal of Feminist Geography, v. 4, n. 1, 1997, pp. 63-88.

ALDERSON, Priscilla; MORROW, Virginia. The Ethics of Research with Children and Young People: A Practical Handbook. London: Sage, 2011.

ANDERSON, Ben; WYLIE, John. On Geography and Materiality. Environment and Planning A, v. 41, n. 2, pp. 318-335. DOI: 10.1068/a3940, 2009.

ANSELL, Nicola. Childhood and the politics of scale: descaling children's geographies? Progress in Human Geography, v. 33, n. 2, pp. 190-209. DOI: 10.1177/0309132508090980, 2009.

BAILEY, Sarah; BODDY, Kasia; BRISCOE, Stuart et al. Involving disabled children and young people as partners in research: a systematic review. Child: Care, Health and Development, v. 41, n. 4, pp. 505-514. DOI: 10.1111/cch.12197, 2015.

BESSELL, Sharon. Rights-based Research with Children: Principles and Practice. In: EVANS, Ruth; HOLT, Louise (Eds). Methodological approaches, v. 2 of Skelton, T. (editor-in-chief) Geographies of children and young people, Singapore: Springer, 2016.

BINGLEY, Amanda. In here and out there: Sensations between Self and landscape. Social \& Cultural Geography, v. 4, n. 3. Taylor \& Francis Group, 2003, pp. 329-345. BONDI, Liz. Empathy and Identification: Conceptual Resources for Feminist Fieldwork. ACME: An International Journal for Critical Geographies, v. 2, n. 1, pp. 64-76, 2002. . Making connections and thinking through emotions: between geography and psychotherapy. Transactions of the Institute of British Geographers, v. 30, n. 4, 2005, pp. 433-448.

. On Freud's Geographies. In: KINGSBURY, Paul; PILE, Steve (Eds). Psychoanalytic Geographies. Farnham: Ashgate, pp. 57-72, 2014.

BOURDIEU, Pierre. Distinction: A social critique of the judgement of taste. Cambridge MA: Harvard University Press, 1984.

BOURDIEU, Pierre; THOMPSON, John. Language and symbolic power. Cambridge MA: Harvard University Press, 1991.

BOWLBY, John. Attachment And Loss. v. 2. New York: Basic Books, 1973.

. A secure base: Clinical applications of attachment theory. London: Routledge, 2005 .

The making and breaking of affectional bonds. London: Tavistock, 2005. 
BOWLBY, Sophie. Women, Work and the Family: Control and Constraints. Geography, V. 75, n. 1, pp. 17-26, 1990.

BOYER, Kate. 'The way to break the taboo is to do the taboo thing' breastfeeding in public and citizen-activism in the UK. Health \& place, v. 17, n. 2, pp. 430-437, 2011. BOYER, Kate; REIMER Suzanne; IRVINE, Lauren. The nursery workspace, emotional labour and contested understandings of commoditised childcare in the contemporary UK. Social \& Cultural Geography, v. 14, n. 5, pp. 517-540, 2013.

BRETHERTON, Inge. The origins of attachment theory: John Bowlby and Mary Ainsworth. Developmental psychology. v. 28, n. 5, 759 p., 1992.

BROWNLIE, Julie; LEITH VALERIE M. SHEACH. Social bundles: Thinking through the infant body. Childhood, v. 18, n. 2, pp. 196-210, 2011.

BULLER, Henry. Animal geographies II. Progress in Human Geography, v. 39, n. 3, pp. 374-384. DOI: 10.1177/0309132514527401, 2015.

BUSHIN, Naomi. Researching family migration decision-making: a children-in-families approach. Population, Space and Place, v. 15, n. 5, pp. 429-443. DOI: 10.1002/ psp.522, 2009.

BUTLER, Judith. The Psychic Life of Power: Theories in Subjection. Stanford, Ca: Stanford University Press, 1997. Performativity's Social Magic. In: SHUSTERMAN, Richard. (ed.). Bourdieu: A Critical Reader. Oxford: Blackwell, pp. 113-128, 1999. Undoing gender. New York: Routledge, 2004.

CALLARD, Feliciy. The taming of psychoanalysis in geography. Social \& Cultural Geography, v. 4, n. 3, pp. 295-312. DOI: 10.1080/14649360309071, 2003.

CAMPBELL, Fiona Kumari; CONTI, Gabriella; HECKMAN, JAMES. J. et al. Early childhood investments substantially boost adult health. Science, v. 343, n. 6178, pp. 1478-85. DOI: 10.1126/science.1248429, 2014.

CAMPBELL, Fiona Kumari. Contours of ableism: the production of disability and abledness. London: Palgrave Macmillan, 2009.

CANGUILHEM, Georges. The Normal and the Pathological. New York: Zone Books, 1973. COCKS, ALISON J. The Ethical Maze. Childhood, v. 13, n. 2, pp. 247-266, 2006.

CORTES-MORALES, Susana; CHRISTENSEN, Pia. Unfolding the pushchair. Children's Mobilities and Everyday Technologies. Research on Education and Media, v. 6, n. 2, Edizioni Erickson: pp. 9-18, 2014.

CRESSWELL, Tim. In place-out of place: geography, ideology, and transgression. Minneapolis: University of Minnesota Press, 1992.

DAVIES, Gail; DWYER, Claire. Qualitative methods: are you enchanted or are you alienated? Progress in Human Geography, v. 31, n. 2. Sage publicationssage CA: Thousand Oaks, CA: 257-266. DOI: 10.1177/0309132507076417, 2007. 
DE CAMPOS TEBET, Gabriela Guarnieri. Geography of infants: following infants's movements and networks. In: Fourth International Conference on Geographies of Children, Youth and Families, San Diego, January 2015, 2015.

DE CAMPOS TEBET, Gabriela Guarnieri; ABRAMOWICZ, Anete. O bebê interroga a sociologia da infância. Linhas Críticas. v. 20, n. 41, pp. 43-61, 2014.

DUNCAN, Simon. Mothering, Class and Rationality. The Sociological Review, v. 53, n. 1. Blackwell Publishing Ltd.: 50-76. DOI: 10.1111/j.1467-954X.2005.00503.X, 2005. DUNCAN, Simon; EDWARDS, Rosalind; REYNOLDS, Tracey. et al. Mothers and child care: policies, values and theories. Children \& Society, v. 18, n. 4. Blackwell Publishing Ltd: pp. 254-265. DOI: 10.1002/chi.800, 2004.

DYCK, Isabel. Feminist geography, the 'everyday', and local-global relations: hidden spaces of place-making*. Canadian Geographer / Le Géographe canadien, v. 49, n. 3, pp. 233-243. DOI: 10.1111/j.0008-3658.2005.00092.x, 2005.

DYER, Sara; DEMERITT, David. Un-ethical review? Why it is wrong to apply the medical model of research governance to human geography. Progress in Human Geography, v. 33, n. 1, pp. 46-64, 2008.

EDWARDS, Claire; IMRIE, Rob. Disability and bodies as bearers of value. Sociology, v. 37, n. 2, pp. 239-256, 2003.

ENGLAND, Kim. Who Will Mind the Baby? Geographies of Childcare and Working Mothers. In: ENGLAND, Kim (ed.) Who Will Mind the Baby? Geographies of Childcare and Working Mothers. London/New York: Routledge, pp. 2-18, 1996.

FAIRCLOTH, Charlotte. Militant lactivism? attachment parenting and intensive motherhood in the UK and France. Oxford: Berghahn Books, 2013.

. The History of Sexuality, Volume 1: An Introduction, trans. Robert Hurley. New York: Pantheon, 1978.

. Abnormal: lectures at the College de France, 1974-1975. New York: Picador, 2003.

GABB, Jaqui. 'I Could Eat My Baby to Bits'; passion and desire in lesbian mother-children love. Gender, Place \& Culture, v. 11, n. 3, pp. 399-415, 2004.

GALLACHER, Lesley Anne. 'The terrible twos': Gaining control in the nursery? Children's Geographies, v. 3, n. 2, pp. 243-264, 2005.

From milestones to wayfaring: geographic metaphors and iconography of embodied growth and change in infancy and early childhood. Geohumanities in press, 2018.

GALLACHER, Lesley Anne; GALLAGHER, Michael. Methodological Immaturity in Childhood Research? Childhood, v. 15, n. 4, pp. 499-516, 2008.

GALLAGHER, Aisling. The Politics of Childcare Provisioning: A Geographical Perspective. Geography Compass, v. 7, n. 2, pp. 161-171, 2013. 
GRANT, Aimee. 'I... Don't want to see you flashing your bits around': Exhibitionism, othering and good motherhood in perceptions of public breastfeeding. Geoforum 71, pp. 52-61, 2016.

GREED, Clara. Women and planning: creating gendered realities. London/New York: Routledge, 1994.

HALL, Edward; WILTON, Robert. Towards a relational geography of disability. Progress in Human Geography: 309132516659705, 2016.

HANCOCK, Roger; GILLEN, Julia. Safe places in domestic spaces: Two-year-olds at play in their homes. Children's Geographies, v. 5, n. 4, pp. 337-351, 2007.

HARRISON, Paul. Corporeal Remains: Vulnerability, Proximity, and Living on after the End of the World. Environment and Planning A, v. 40, n. 2, pp. 423-445. DOI: 10.1068/a391, 2008.

HART, Roger. Children's experience of place. Oxford: Irvington, 1979.

HOLLOWAY, Sarah L. Local Childcare Cultures: Moral geographies of mothering and the social organisation of pre-school education. Gender, Place \& Culture, v. 5, n. 1, pp. 29-53. DOI: 10.1080/09663699825313, 1998.

. Changing children's geographies. Children's Geographies, v. 12, n. 4, pp. 377392, 2014.

HOLLOWAY, Sarah L.; HOLT, Louise; MILLS, Sarah. Questions of agency: Capacity, subjectivity, spatia.lity and temporali. Progress in Human Geography. In press, 2018. HOLT, Louise. Children's sociospatial (re)production of disability within primary school playgrounds. Environment and Planning D: Society and Space, v. 25, n. 5. DOI: $10.1068 / \mathrm{d} 73 \mathrm{j}$, 2007.

. Embodied social capital and geographic perspectives: Performing the habitus. Progress in Human Geography, v. 32, n. 2. DOI: 10.1177/0309132507087648, 2007.

. Embodying and destabilising disability and childhood. In: Hörschelmann K and Colls R (eds). Contested bodies of childhood. Basingstoke, UK: Palgrave Macmillan, pp. 201-215, 2009.

Geographies of children, youth and families: an international perspective. Taylor \& Francis, 2010.

. Exploring the emergence of the subject in power: infant geographies. Environment and Planning D: Society and Space 31, pp. 645-663, 2013.

Food, feeding and the material everyday geographies of infants: possibilities and potentials. Social \& Cultural Geography, pp. 1-18. DOI: 10.1080/14649365.2016.1193889, 2016.

HOLT, Louise; HOLLOWAY, Sarah. L. Editorial: Theorising other childhoods in a globalised world. Children's Geographies, v. 4, n.2.DOI:10.1080/14733280600806817, 2006. 
HOLT, Louise. BOWLBY, Sophie; LEA, Jennifer.'Everyone knows me.... I sort of like move about': The friendships and encounters of young people with Special Educational Needs in different school settings. Environment and Planning A, v. 4, n. 6, pp. 1361-1378. DOI: 10.1177/0308518X17696317, 2017.

HOPKINS, Peter. Young people, place and identity. London: Routledge, 2013.

HORTON, John; KRAFTL, Peter. What else? Some more ways of thinking and doing 'Children's Geographies'. Children's Geographies, v. 4, n. 1. Routledge, pp. 69-95. DOI: 10.1080/14733280600577459, 2006.

Small acts, kind words and 'not too much fuss': Implicit activisms. Emotion, Space and Society. V. 2, n. 1. Elsevier, pp. 14-23. DOI: 10.1016/J.EMOSPA.2009.05.003, 2009.

Tears and laughter at a Sure Start Centre: toddlers' geographies, policy contexts. In: Geographies of Children, Youth and Families: An International Perspective. London/New York: Routledge, pp. 235-249. 2011.

IMRIE, Rob. Space, place and policy regime. In: SOLDATIC, Karen, MORGAN, Hannah; ROULSTONE, Aalan. (eds) Disability, Spaces and Places of Policy Exclusion. Disability Spaces and Places of Policy Exclusion. Routledge, pp. 13-29, 2014.

JAMES, Allison; JENKS, Chris; PROUT, Alan. Theorizing Childhood. Williston, VT: Teachers College Press, 1998.

JARVIS, Helen; PRATT, Andy; WU, Peter Cheng-Chong. The secret life of cities: social reproduction of everyday life. London/New York: Routledge, 2013.

JENKS, C. A sociological approach to childhood development. In: SMITH, P. K.; HART, Craig H. (Eds). The Handbook of Child Development. Oxford: Blackwell, pp. 78-94, 2004.

JENSEN, Tracey; TYLER, Imogen. Austerity Parenting: new economies of parent-citizenship. Studies in the Maternal, v. 4, n. 2. Open Library of Humanities. DOI: 10.16995/sim.34, 2012.

JUPP, Eleanor. Enacting parenting policy? The hybrid spaces of Sure Start Children's Centres. Children's Geographies, v. 11, n. 2, pp.173-187, 2013.

KATZ, Cindi. Playing the field: questions of fieldwork in geography. The Professional Geographer, v. 46, n. 1, pp. 67-72, 1994.

. On the grounds of globalization: a topography for feminist political engagement. Signs: 1213-1234, 2001.

Growing up global: Economic restructuring and children's everyday lives. Minneapolis, MN: University of Minnesota Press, 2004.

KENNY, Dianna Theadora. Bringing up baby: the psychoanalytic infant comes of age. London: Karnac Books, 2013.

KINGSBURY, Paul. Psychoanalysis, a gay spatial science? Social \& Cultural Geography, v. 4 , n. 3, pp. 347-367, 2003. 
KITCHIN, Rob. 'Out of Place', 'Knowing One's Place': Space, power and the exclusion of disabled people. Disability \& Society, v. 13, n. 3, pp. 343-356. DOI: 10.1080/09687599826678, 1998.

KRAFTL, Peter; HORTON, John. Spaces of every-night life: for geographies of sleep, sleeping and sleepiness. Progress in Human Geography, v. 32, n. 4, pp. 509-524, 2008. LONGHURST, Robyn. Maternities: Gender, bodies and space. London: Routledge, 2008.

Youtube: a new space for birth. Feminist Review, v. 93, n. 1, pp. 46-63, 2009.

LORIMER, Hayden. Cultural geography: non-representational conditions and concerns. Progress in Human Geography, v. 32, n. 4, pp. 551-559. DOI: 10.1177/0309132507086882, 2008.

LUPTON, Deborah. Infant embodiment and interembodiment: A review of sociocultural perspectives. Childhood, v. 20, n. 1, pp. 37-50, 2013.

MADGE, Clare; O'CONNOR, Henrietta. Mothers in the making? Exploring liminality in cyber/space. Transactions of the Institute of British Geographers, v. 30, n. 1, pp. 83-97. DOI: 10.1111/j.1475-5661.2005.00153.x, 2005.

MADGE, Clare; O'CONNOR, Henrietta. Mothers in the making? Exploring liminality in cyber/space. Transactions of the Institute of British Geographers, v. 30, n. 1, pp. 83-97. DOI: 10.1111/j.1475-5661.2005.00153.x, 2005.

MANSFIELD, B. The social nature of natural childbirth. Social science \& medicine, v. 66, n. 5, pp. 1084-1094, 2005.

MATTHEWS, M. H.; VUJAKOVIC, Peter. Private Worlds and Public Places: Mapping the Environmental Values of Wheelchair Users. Environment and Planning A, v. 27, n. 7, pp. 1069-1083. DOI: 10.1068/a271069, 1995.

MCDOWELL, Linda. Reconfigurations of gender and class relations: class differences, class condescension and the changing place of class relations. Antipode, v. 38, n. 4, pp. 825-850, 2006.

Spaces of the Home: Absence, Presence, New Connections and New Anxieties. Home Cultures, v. 4, n. 2. Routledge, pp. 129-146. DOI: 10.2752/174063107X208993, 2007. . The new economy, class condescension and caring labour: changing formations of class and gender. NORA-Nordic Journal of Feminist and Gender Research, v. 16, n. 3, pp. 150-165, 2008.

MCDOWELL, Linda; RAY, Kathryn; PERRONS, Diane; et al. Women's paid work and moral economies of care. Social \& Cultural Geography, v. 6, n. 2. Taylor \& Francis groupabingdon, UK: pp. 219-235. DOI: 10.1080/14649360500074642, 2005.

MCDOWELL, Linda; WARD, Kevin; PERRONS, Diane; et al. Place, Class and Local Circuits of Reproduction: Exploring the Social Geography of 
Middle-class Childcare in London. Urban Studies, v. 43, n. 12, pp. 2163-2182. DOI: 10.1080/00420980600936509, 2006.

MCNAY, Lois. Foucault: A critical introduction. New York: Continuum, 1994.

NOSWORTHY, Cheryl. A Geography of Horse-Riding: the Spacing of Affect, Emotion and (Dis)ability Identity through Horse-Human Encounters. Cambridge: Cambridge Scholars Publishing, 2013.

PAIN R.; BAILEY C.; MOWL G. Infant feeding in North East England: contested spaces of reproduction. Area, v. 33, n. 3, pp. 261-272. DOI: 10.1111/1475-4762.00030, 2001.

PAINTER J.; PIERRE, Bourdieu. In: CRANG, Mike; THRIFT, Nigel J. (ed.) Thinking space. First. London: Routledge, pp. 239-259, 2000.

PEAKE, Linda. The Suzanne Mackenzie Memorial Lecture: Rethinking the politics of feminist knowledge production in Anglo-American geography. The Canadian Geographer / Le Géographe canadien, v. 59, n. 3, pp. 257-266. DOI: 10.1111/ cag.12174, 2015 .

PHILO, Chris. A vitally human medical geography? Introducing Georges Canguilhem to geographers. New Zealand Geographer, v. 63, n. 2. Blackwell Publishing Asia, pp. 82-96. DOI: 10.1111/j.1745-7939.2007.00095.x, 2007.

PHILO, Chris; PARR, Hester. Introducing psychoanalytic geographies. Social \& Cultural Geography, v. 4, n. 3, pp. 283-293, 2003.

PILE, Steve. The body and the city: Psychoanalysis, space, and subjectivity. London: Routledge, 1996.

PRATT, Geraldine. Working feminism. Philadelphia: Temple University Press, 2004.

PRATT, Geraldine; YEOH, Brenda. Transnational (Counter) Topographies. Gender, Place \& Culture, v. 10, n. 2. Taylor \& Francis Group, pp. 159-166. DOI: 10.1080/0966369032000079541, 2003.

RIDGE, Tess. We are All in This Together'? The Hidden Costs of Poverty, Recession and Austerity Policies on Britain's Poorest Children. Children \& Society, v. 27, n. 5, pp. 406-417. DOI: 10.1111/chso.12055, 2013.

ROSE, Nikolas. Governing the soul: the shaping of the private self. London: Routledge, 1990.

RUDDICK, Sue. At the Horizons of the Subject: Neo-liberalism, neo-conservatism and the rights of the child Part One: From 'knowing' fetus to 'confused' child. Gender, Place and Culture, v. 14, n. 5, pp. 513-527, 2007.

. At the Horizons of the Subject: Neo-liberalism, neo-conservatism and the rights of the child Part Two: Parent, caregiver, state. Gender, Place \& Culture, v. 14, n. 6, pp. 627-640. DOI: 10.1080/09663690701659101, 2007.

SHILDRICK, Margrit. Becoming-maternal: things to do with Deleuze. Studies in the Maternal, v. 2, n. 1. DOI: 10.16995/sim.91, 2010. 
SHILLING, Chris. The body and social theory. London: Sage, 2013.

SHONKOFF, Jack P.; PHILLIPS D. A.; NATIONAL RESEARCH COUNCIL (U.S.). Committee on Integrating the Science of Early Childhood Development. From neurons to neighborhoods: the science of early child development. Washington: National Academy Press. Skelton T (Ed.) (2015) Geographies of Children and Young People. Singapore: Springer, 2000.

SMITH, Darren. P; PHILLIPS D. A. Socio-cultural representations of greentrified Pennine rurality. Journal of Rural Studies, v. 17, n. 4. Pergamon, pp. 457-469. DOI: 10.1016/So743-0167(01)00014-6, 2001.

SMITH, Karen. (n.d.) The government of childhood: discourse, power and subjectivity. Palgrave Macmillan.

STERN, Daniel. Interpersonal world of the infant: A view from psychoanalysis and development psychology. London: Basic books, 2006.

SWAIN, John; FRENCH, Sally; BARNES, Colin. et al. (Eds) Designing inclusive environments and the significance of universal design. In: Disabling barriers - enabling environments. Los Angeles: Sage, pp. 287-298, 2014.

TIVERS, Jacqueline. Women attached: the daily lives of women with young children. Maidstone: Croom-Helm, 1985.

WOOD, Denis; BECK, Robert J.; WOOD I. Home rules. Baltimore MD: Johns Hopkins University Press, 1994.

WOODYER, Tara. The body as research tool: embodied practice and children's geographies. Children's geographies, v. 6, n. 4, pp. 349-362, 2008.

Recebido em 23/01/2018

Aprovado em 05/06/2018

\section{Como citar este artigo:}

HOLT, Louise. Retrieving the hidden everyday spaces of infants. Contemporânea Revista de Sociologia da UFSCar, v. 8, n. 2, jul.- dez. 2018, pp. 407-440. 